\title{
Influence Of Corporate Social Responsibility On Hotel Demand
}

Claudia Sevilla-Sevilla, Universidad Nacional de Educación a Distancia (UNED), Spain

María Dolores Reina-Paz, Universidad Nacional de Educación a Distancia (UNED), Spain Ainhoa Rodríguez-Oromendía, Universidad Nacional de Educación a Distancia (UNED), Spain

\begin{abstract}
The embrace of corporate social responsibility (CSR) by the Spanish hospitality industry is still in the early stages. Few hotel companies publish sustainability reports, although the number of tourism and distribution channel organizations (tour operators, online travel agencies, etc.) incorporating specific aspects of CSR is growing each year. In this paper, the authors analyze whether CSR has a direct effect on end-consumer demand in Spain, identifying those aspects that customers evaluate positively.
\end{abstract}

Keywords: Corporate Social Responsibility; Tourism; Hospitality Industry

\section{INTRODUCTION}

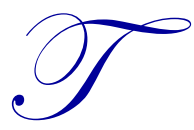

hroughout history, companies have been viewed as organizations whose primary purpose was to obtain economic benefits. According to Friedman (1970), the sole social responsibility of business is to maximize profits (Galbreath, 2009; Bosch, Montllor and Tarrazon, 2013). More recently, new approaches to sustainable development, based on the Brundtland Report (World Commission On Environment And Development, 1987), have proliferated and organizations are now expected to assume some degree of social responsibility and to engage in responsible conducts that allow them to meet the needs of today without compromising the ability to meet the needs of future generations as well (Martos, 2011).

The literature on CSR is extensive, but academics and professionals have yet to agree on a general definition (Carroll, 1999; Pearce and Doh, 2005). Even at the practical level, despite all that has been written on the desirability of integrating CSR into overall business strategies, there continues to be confusion regarding how to do so without running the risk of equating CSR with a code of ethics and/or a public relations campaign, two approaches that are considered to be too limited (Galbreath, 2009).

CSR has sometimes been likened to a sort of business ethics, and several authors have explicitly rejected the separation of purely economic concerns from ethical ones on the grounds that it is essentially impossible to do (Freeman and Harris, 2008).

The concept of CSR has evolved and has come to include references to the need for organizations to reinvest a portion of their profits in society in order to create shared value for stakeholders and, thus, to enhance corporate, environmental and social sustainability. This triple bottom line - economic, social and environmental - is widely accepted in the sphere of CSR. Although originally understood as merely a collateral activity, CSR has today come to form part of the core corporate strategy (Bosch, Montllor and Tarrazon, 2013).

CSR can be understood as the commitment that companies undertake to improve community welfare through discretional business practices and the contribution of corporate resources (Kotler and Lee, 2005). Alternatively, it can be understood as a way of conducting business that takes into account the impacts that all aspects of a company's operations have on clients, employees, shareholders, local communities, the environment and society at large (Observatorio de Responsabilidad Social Corporativa, 2009; Fernández and Cuadrado, 2011). 
The long-term effect of CSR policies and measures compensates for the implementation thereof with an increase in market-based firm value; therefore, companies should not pursue it solely in the hopes of achieving short-term gains (Kang and Huh, 2010). The emphasis traditionally placed on the pursuit of short-term profit, together with organizations' fuzzy perception of CSR, has slowed the adoption of new management models.

As for these perceptions themselves, differences can even be found between countries which neither perceive nor value corporate conduct and the primary CSR issues the same way (Farber and Vincent, 2013).

Most current CSR theories focus on four main aspects: 1) objectives that generate long-term profits, 2) objectives that use corporate power responsibly, 3) objectives that integrate social demands, and 4) objectives that contribute to creating a good society, doing what is ethically right (Garriga and Melé, 2004).

The key to unlocking the next wave of business innovation and growth will be shared value creation. Business success must once again be linked to the success of the community in order to overcome an age of narrowminded management approaches and short-term thinking that have deepened social divides (Porter and Kramer, 2011).

At the attitudinal level, CSR in Spain has suffered a setback and is met with growing skepticism. Likewise, in terms of actual behavior, certain business practices and consumer habits have experienced cutbacks. Nevertheless, the discourse in favor of CSR continues to gain momentum in medium-sized and large companies, which will largely offset the decline among smaller companies due to the driver effect of large companies on small ones (Foro Para La Evaluación De La Gestión Ética [FORÉTICA], 2011).

\section{CSR In The Tourism Industry}

The tourism industry has evolved quite quickly in recent years. Technology has fostered a radical change in both tourism distribution channels and consumers' buying habits. The literature on sustainable tourism has largely and selectively ignored the implications of this for environmental management policies at tourism destinations (Blanco, Rey-Maquieira and Lozano, 2009).

As in other industries, in the tourism industry, differences can be found in sector professionals' perceptions of and moral philosophies concerning CSR, which could be related to cultural differences (Ruhi and Gurel, 2006).

The complexity of tourism destinations, due to the necessary involvement of multiple stakeholders (service providers, residents, resource and infrastructure managers, etc.), requires each stakeholder to assume a certain degree of responsibility toward the destination's other stakeholders and to be aware of the impact of its actions on them (Martos, 2011).

Tour operators should take an active concern in their social, economic and environmental performance and thus, through their actions, offer guidance to consumers seeking to support sustainable tourism (Miller, 2001).

\section{CSR In The Hospitality Industry}

For the hospitality industry to develop at a tourism destination, the availability of natural resources must be constant. A destination's natural resources are both one of its main tourism-related assets and one of the features most directly threatened by potential overexploitation (Bohdanowicz, 2005). It is thus sometimes necessary to both tighten regulations on businesses and to engage the tourism industry in environmental conservation efforts. According to Fernández and Cuadrado (2011), hotel companies, as a vital link in the tourism industry's chain of activities, play a particularly important role in the implementation of social responsibility policies, both through their contribution in terms of income and employment (World Travel and Tourism Council, 2009) and as a result of their environmental (Bohdanowicz, 2005), economic, and social impact (Brunt and Courtney, 1999).

Hotel chains have been trailblazers in the development and implementation of CSR in Spain, although the specific degree of implementation in the tourism industry varies considerably (Rodríguez, Alonso and Celemin, 2013). 
According to Bohdanowicz (2005), to achieve greater implementation of CSR in the industry, two main conditions must be met:

- Hotels must embrace environmental good practice in order to demonstrate the cost savings it entails.

- Customers' awareness regarding environmental issues must be raised in order to increase the demand for "green" alternatives.

A clear dichotomy can be seen in the approaches taken in the research published on the hospitality industry. On the one hand, there are exploratory and analytical case studies that seek to study hotels' environmental and social management practices; on the other, there are quantitative case studies focused on profitability and the economic and financial impact of the CSR policies that have been implemented (Fernández and Cuadrado, 2011). Models can even be found suggesting that employees' perceptions of hospitality organizations' CSR efforts can yield certain psychological and symbolic benefits that cause them to identify more strongly with the company and, thus, lead to more profitable behavioral responses for the firm (Alvarado and Hernández, 2011).

Fewer and fewer researchers question the usefulness of CSR to enhancing a company's value (Kang and Huh, 2010). Instead, CSR is largely viewed as a fruitful long-term investment and a differentiating factor for companies, whether it stems from a genuine change of mindset or simply the pursuit of profit (Martos, 2011).

According to Rodríguez, Alonso and Celemin (2013), most hotel chains have focused on the environmental dimension of CSR, primarily as a means of offering more sustainable services, achieving cost savings and reaching new market segments (Enz and Siguaw, 1999; Goodman, 2000; Alvarez, Burgos and Céspedes, 2001; Carmona, Céspedes and Burgos, 2004; Molina, Claver, Pereira and Tarí, 2009; López, Molina and Claver, 2009; Alonso and Rodriguez, 2011; Rodríguez, Alonso and Celemin, 2013). However, tourism companies' actions, with regard to the social dimension of CSR, remain largely unstudied (Bohdanowicz and Zientara, 2008; De Grosbois, 2012) as it has not been widely embraced by any of the tourism subsectors.

With regard to demand, customers' preferences are changing. There is still relatively little quantitative data on how and how highly consumers value companies' socially responsible actions (Fernández and Merino, 2005). Companies and consumers operate with different definitions of CSR; while these understandings are not mutually exclusive, they can lead to differences in terms of meeting each other's expectations (FORÉTICA, 2008).

The literature on CSR has, likewise, rarely focused on consumers. This, coupled with the divergent results of studies aimed at determining which CSR dimensions consumers perceive, as well as the generally exploratory nature thereof, among other things, has led to the identification of specific gaps in the knowledge (Alvarado, 2008).

Consumers have great potential to shape the future development of tourism. This potential largely stems from either their ability to censure irresponsible actions or the promise of marketing advantages, and companies will have to monitor their performance accordingly (Miller, 2001).

\section{Influence Of CSR On Spanish Hotel Demand}

The main question that this study sought to answer was whether or not the implementation of CSR actions by hotels positively impacts consumers' perceptions of their services. It moreover sought to determine whether such actions have any effect on whether or not tourism consumers ultimately decide to contract a given service.

To facilitate the field work, Spain's Internet user market was used as the study population. According to ONTSI (2013), there are 15.2 million online shoppers in Spain and the two leading products for this market both belong to the tourism industry - tickets for travel and accommodation bookings.

A sample of 385 individuals was randomly selected from this universe of 15.2 million people (with a confidence level of $95 \%$ and a margin of error of $\underline{ \pm} \%$ ) and sent an online survey. 
To study consumers' perceptions of hotels' CSR actions (i.e., the value they attach to them), three kinds of variables were defined - economic CSR variables (ec-CSRs), environmental CSR variables (en-CSRs), and social CSR variables (so-CSRs).

It was thus possible to study various aspects (subvariables), as well as the value or importance that consumers give to them, for each of the three variable categories.

According to the study's results, $70 \%$ of the respondents prefer to stay at 3- or 4-star hotels.

With regard to economic aspects (ec-CSRs), the most important factor for the respondents was the availability of competitive prices ( $77 \%$ of the sample), followed by discounts and/or some other type of end benefit for loyal customers $(71 \%)$.

With regard to environmental aspects (en-CSRs), consumers attached the greatest importance to watersaving measures, such as water sensors and timers, high-pressure low-flow shower heads, dual-flush toilets, and/or systems for allowing guests to indicate when they would like to have their sheets and towels changed so as to avoid doing it daily. Curiously, respondents did not consider it important for hotels to convey their commitment to the environment to guests or to encourage guests to collaborate during their stay by suggesting simple steps they could take to help. Likewise, it was not considered particularly important for hotels to publish regular environmental performance reports.

As for social aspects (so-CSRs), 56\% of respondents believed it was very important for the company to have a code of ethics and to ensure respect for human rights. Likewise, $63 \%$ of respondents considered it essential for the hotel to treat its employees fairly by implementing policies to ensure non-discriminatory hiring practices and pay equity and to facilitate work-life balance. Conversely, little importance was attached to whether a hotel has procedures in place for contracting only suppliers that implement their own environmental and sustainability measures and policies.

It is worth noting that the brunt of respondents claimed to have no knowledge of which hotel chain has the strongest social and environmental performance (64\%). The only chain considered to be respectful of both social and environmental aspects was Paradores (11\%), which is run by the Spanish government. It was followed by NH Hoteles (9\%) and Melià Hotels International (4\%).

\section{CONCLUSIONS AND FUTURE RESEARCH}

The foregoing analysis highlights how little hotel service users know about the kinds of CSR initiatives carried out by the hospitality industry. While end customers do positively value certain actions related to energy efficiency and natural resource savings and expect organizations to follow a code of ethics, the most decisive factor for hotel users is an establishment's ability to offer competitive prices.

Future research should seek to determine whether measures related to the implementation of CSR, as part of the core corporate strategy, can play a decisive role in consumers' decisions when making bookings; whether hotel chains that have already incorporated CSR into their strategies have experienced stronger economic performance; and what the best actions are, from the consumer's perspective, for enhancing corporate identity.

\section{AUTHOR INFORMATION}

Claudia Sevilla-Sevilla holds a degree in geography and history from the University of Barcelona and postgraduate degree in leisure and tourism studies from the London Metropolitan University. She is an associate professor of economics in the Business and Accounting Department of the Faculty of Economics and Business Administration at the Universidad Nacional de Educación a Distancia (National University of Distance Teaching, UNED) in Spain. Her research interests include marketing, corporate social responsibility, the hospitality industry and tourism. Phone: +34 675897190; fax: +34 91 3987355; e-mail: csevilla@cee.uned.es. 
María Dolores Reina-Paz holds a PhD in business from UNED. She is an assistant professor of economics in the Business and Accounting Department of the UNED Faculty of Economics and Business Administration. Her research interests include: marketing, corporate social responsibility, consumers and tourism. Phone +34 649946034; fax +34 91 3987355; e-mail: mreina@cee.uned.es.

Ainhoa Rodríguez-Oromendía holds a $\mathrm{PhD}$ in business from UNED. She is an assistant professor of economics in the Business and Accounting Department of the UNED Faculty of Economics and Business Administration. Her research interests include: trade-show marketing, tourism and tourist behavior. Phone +34 606243177; fax +3491 3986374; and e-mail: arodriguez@cee.uned.es.

\section{REFERENCES}

1. ALONSO, M. M. \& RODRIGUEZ, J. M. (2011). Organisational behaviour and strategies in the adoption of certified management systems: an analysis of the Spanish hotel industry, Journal of Cleaner Production, 19(13), 1455-1463.

2. ALVARADO, A. (2008). Responsabilidad social empresarial percibida desde una perspectiva sostenicéntrica, y su influencia en la reputación de la empresa y en el comportamiento del turista. Universitat de Valéncia. Retrieved from: http://www.tdx.cat/handle/10803/9468.

3. ALVARADO, A. \& HERNÁNDEZ, G. (2011). "Modelo para establecer la influencia de la responsabilidad social empresarial en el desempeño de los empleados de hoteles." Teoría y praxis, 10:9-19.

4. ALVAREZ M. J., BURGOS J. \& CÉSPEDES, J. J. (2001). An analysis of environmental management, organizational context and performance of Spanish hotels, Omega, 29(6), 457-471.

5. BLANCO, E., REY-MAQUIEIRA, J., \& LOZANO, J. (2009). Economic incentives for tourism firms to undertake voluntary environmental management, Tourism Management, 30(1), 112-122.

6. BOHDANOWICZ, P. (2005). European Hoteliers' Environmental Attitudes: Greening the Business, Cornell Hotel and Restaurant Administration Quarterly, 46(2), 188-204.

7. BOHDANOWICZ, P. \& ZIENTARA, P. (2008). Corporate Social Responsibility in Hospitality: Issues and Implications. A Case Study of Scandic, Scandinavian Journal of Hospitality and Tourism, 8(4), 271-293.

8. BOSCH, M. T., MONTLLOR, J., \& TARRAZON, M. A. (2013). Corporate Social Responsibility from Friedman to Porter and Kramer, Theoretical Economics Letters, 3, 11-15.

9. BRUNT, P. and COURTNEY, P. (1999). Host perceptions of sociocultural impacts, Annals of Tourism Research, 26(3), 493-515.

10. WORLD COMMISSION ON ENVIRONMENT AND DEVELOPMENT. (1987). Our common future (Vol. 383). Oxford: Oxford University Press.

11. CARMONA, E., CÉSPEDES, J. and BURGOS, J. (2004). Environmental Strategies in Spanish Hotels: Contextual Factors and Performance, The Service Industries Journal, 24(3), 101-130.

12. CARROLL, A. B. (1999). Corporate Social Responsibility: Evolution of a Definitional Construct, Business and Society, 38(3), 268-295.

13. DE GROSBOIS, D. (2012). Corporate social responsibility reporting by the global hotel industry: Commitment, initiatives and performance. International Journal of Hospitality Management, 31 (3), 896905.

14. ENZ, C. A. and SIGUAW, J. A. (1999). Best Hotel Environmental Practices, Cornell Hotel and Restaurant Administration Quarterly, 40(5), 72-77.

15. FARBER, V. \& VINCENT, C. (2013). La percepción de la RSC, ¿depende del país? Un estudio sobre la reputación de las empresas españolas en América Latina sobre la base de la RSC, ESIC Market: Economic and Business Journal, 44(2), 37-65.

16. FERNÁNDEZ, D. \& MERINO, A. (2005). ¿Existe disponibilidad a pagar por responsabilidad social corporativa? Percepción de los consumidores, Universia Business Review-Actualidad Económica, Tercer Trimestre.

17. FERNÁNDEZ, M. T. \& CUADRADO, R. (2011). La responsabilidad social empresarial en el sector hotelero: revisión de la literatura científica, Cuadernos de Turismo, 28, 47-57.

18. FORO PARA LA EVALUACIÓN DE LA GESTIÓN ÉTICA (FORÉTICA). (2008). Informe FORÉTICA 2008, evolución de la responsabilidad social de las empresas en España. Madrid: FORÉTICA.

19. FORO PARA LA EVALUACIÓN DE LA GESTIÓN ÉTICA (FORÉTICA). (2011). Informe FORÉTICA 
2011, evolución de la responsabilidad social de las empresas en España. Madrid: FORÉTICA.

20. FREEMAN, R. E. \& HARRIS, J. D. (2008). The Impossibility of the Separation Thesis: A Response to Joakim Sandberg, Business Ethics Quarterly, 18(4), 541-548.

21. FRIEDMAN, M. (1970). The Social Responsibility of Business Is to Increase Its Profits, The New York Times Magazine, September 13, 32-33, 122, 124, 126.

22. GALBREATH, J. (2009). Building corporate social responsibility into strategy, European Business Review, 21(2), 109-127.

23. GARRIGA, E. and MELÉ, D. (2004). Corporate Social Responsibility Theories: Mapping the Territory, Journal of Business Ethics, 53(1-2), 51-71.

24. GOODMAN, A. (2000). Implementing Sustainability in Service Operations in Scandic Hotels, Interfaces, 30(3), 202-214.

25. KANG, K., LEE, S. \& HUH, C. (2010). Impacts of positive and negative corporate social responsibility activities on company performance in the hospitality industry, International Journal of Hospitality Management, 29(1), 72-82.

26. KOTLER, P. \& LEE, N. (2005). Corporate Social Responsibility: Doing the Most Good for Your Company and Your Cause. Hoboken, New Jersey: John Wiley \& Sons, Inc.

27. LÓPEZ, M. D., MOLINA, J. F. \& CLAVER, E. (2009). The whole relationship between environmental variables and firm performance: competitive advantage and firm resources as mediator variables, Journal of Environmental Management, 90(10), 3110-3121.

28. MARTOS, M. (2011). La responsabilidad social corporativa en la gestión hotelera, Turismo y Sociedad, 12, n/a.

29. MILLER, G. (2001). Corporate responsibility in the UK tourism industry, Tourism Management, 22, 589598.

30. MOLINA, J. F., CLAVER, E., PEREIRA, J. and TARÍ J. J. (2009). Environmental practices and firm performance: an empirical analysis in the Spanish hotel industry, Journal of Cleaner Production, 17, 516524.

31. OBSERVATORIO DE LA RESPONSABILIDAD SOCIAL CORPORATIVA. (2009). ¿Qué es RSC? Retrieved from: http://www.observatoriorsc.org/.

32. ONTSI. (2013). Comercio electrónico B2C 2012. Madrid: ONTSI.

33. PEARCE, J. A. \& DOH, J. P. (2005). The high impact of collaborative social initiatives. MIT Sloan Management Review, 46(3), 30-9.

34. PORTER, M. \& KRAMER, M. (2011). The Big Idea: Creating Shared Value, Harvard Business Review, January-February.

35. RODRÍGUEZ, J. M., ALONSO, M. \& CELEMIN, M. (2013). Responsabilidad social corporativa en las cadenas hoteleras españolas. Un estudio de casos, Revista de Responsabilidad Social de la Empresa, 13.

36. RUHI, Y.\& GUREL, E. (2006). Ethical Ideologies of Tourism Marketers, Annals of Tourism Research, $33(2), 470-489$.

37. WORLD TRAVEL AND TOURISM COUNCIL. (2009). Travel \& Tourism Economic Impact: Spain 2009. Retrieved from: http://www.wttc.org/research/economic-impact-research/country-reports/. 